\title{
CHOOSING TEACHING AS A PROFESSION: VALIDATION OF AN SMVUP-4-S ASSESSMENT TOOL
}

\author{
Robert Tomšik \\ Research Institute for Child Psychology and Pathopsychology, Slovakia \\ E-mail: robert.tomsik@vudpap.sk
}

\begin{abstract}
The aim of the present research was to validate the Scale of motivation for choosing teaching profession (SMVUP-4-S), and to explore its basic psychometric properties on a sample of Slovak teacher trainee students. SMVUP-4-S scale was completed by 1235 respondents with a mean age of 20.1 years. SMVUP4-S scale consists of 44 items arranged into 11 subscales, which are arranged into three main categories of motivation: intrinsic, extrinsic and altruistic. A latent structure of SMVUP model that consists of two four-factor (intrinsic and extrinsic motivation) and a one three-factor model (altruistic motivation) was tested. Internal consistency was assessed using Cronbach's alpha. Exploratory factor analysis (EFA) was calculated using the Maximum Likelihood estimation. To evaluate Confirmatory factor analysis (CFA) $\chi^{2}$-test, CFI, RMSEA, SRMR, AIC, BIC and TLI indicators were used. SMVUP-4-S scale showed an acceptable internal consistency. Using EFA two four-factor and one three-factor model were extracted. CFA indicated that four-factor models had a good fit to the empirical data (Intrinsic motivation $\chi^{2} / d f$ $=4.925$, Extrinsic motivation $\chi^{2} / d f=4.781$ ). Modifying indexes have shown that several items have correlated with residual variances which leads to low fit to the empirical data in three-factor-model. After the implementation of covariants between items this model has also shown a good fit to the empirical data (Altruistic motivation $\chi^{2} / d f=4.715$ ).
\end{abstract}

Keywords: teacher development, teacher motivation, career choice, psychological assessment.

\section{Introduction}

Teacher motivation belongs to one of the most crucial factors in education. Scientific resources have offered numerous studies on teacher motivation in different contexts and time (e.g. Brown, 1992; Fresko, Kfir, \& Nasser, 1997; Joseph \& Green, 1986; Kyriacou \& Coulthard, 2000; Liu, Kardos, Kauffman, Peske, \& Johnson, 2000) but there is a lack of reliable measurement tool for research on this issue, which would allow comparisons across the different settings and a variety of research samples (gender, school level, social and sociocontext, or comparison over time) in the Slovak Republic or other demo-geographic areas. The most frequently used assessment tool for measuring motivation in choosing teaching as a profession, based on literature review, is the validated Fit-Choice Scale (Watt \& Richardson, 2008). However, primarily, the Fit-Choice scale has been constructed to detect the degree of motivation for choosing teaching as a career among Australian teacher training students (an assessment tool was subsequently validated in other countries as well: Casacubierta \& Puig, 2016; Fokkens-Bruinsma, Canrinus, Korpershoek, \& Doolaard, 2015; Nesje, Brandmo, \& Berger, 2017; Tomida \& Miwa, 2018; etc.). Given the specificities of teacher job position and education system in Slovakia, adapting the Fit-Choice model to these conditions has been unsuccessful (Tomšik \& Verešová, 2015). After an unsuccessful attempt to adapt the Fit-Choice 
Robert TOMŠIK. Choosing teaching as a profession: Validation of an SMVUP-4-s assessment tool

PROBLEMS

OF EDUCATION

IN THE $21^{\text {st }}$ CENTURY Vol. 77, No. 4, 2019

546

scale (Tomšik \& Verešová, 2015) and its re-design (Tomšik, 2016c), the Scale of motivation for choosing teaching as a profession SMVUP (hereinafter SMVUP) model has been developed (Tomšik, 2016a) aiming at a more comprehensive and valid examination of the motivation for choosing teaching in the Slovak Republic considering the above mentioned specifications and conditions. Validity and reliability of the SMVUP-3-S scale (third edition for students) have been verified using the Principal Axis Factoring (Varimax rotation). The scale consisted of 11 factors comprising 39 items. In the above version, the research tool had several drawbacks regarding the content of the scales: saturation of factors by several items at a level $>.400$, inadequate adaptation of the content to conditions of Slovakia and insufficient differentiation of subscales. These deficiencies require further correction and implementation of new (or corrected) items into the SMVUP model. The items in this tool have been adapted to the sociocultural specifics, the specific conditions of the educational system and more particularly the peculiarities of the teaching profession in the territory of the Slovak Republic - significant differences are especially indicative for the following factors: previous experience, benefits, income and social status.

SMVUP and Fit-Choice (Watt \& Richardson, 2007) models of motivation for choosing teaching as a career are based on the theory of expectation and values (Eccles \& Wigfield, 2002) and work motivation (Holland, 1985) and self-determination theory (Ryan $\&$ Deci, 2000). Presuming the impact of various social factors on the personality that are the decisive factors in the career choices, the impact of socio-cultural, family environment, peers, personality and other influences can be considered to be significant determinants of the career choice. The model of motivation for choosing teaching as a career point to different psychological mechanisms that are involved in the process of choosing teaching as a career, but all parts of the model work together in the decision-making process (Tomšik, 2016b; Watt \& Richardson, 2012). Specific motives for choosing teaching as the career, theoretical and empirical findings (Watt, Richardson, \& Devos, 2013; Saban, 2003; Schutz, Crowder, \& White, 2000) most often are categorized into the following three categories: intrinsic, extrinsic and altruistic motivation. Intrinsic motivation impulse comes from the inner personality structures. It is, therefore, more durable and effective compared to the other types of motivation (Klein, 2006). Intrinsic motives are the most frequent when teaching as a career is chosen. They are considered the most important because they are directly related to the content of career (Watt, Richardson, \& Devos, 2013), and they are predominately good as for professional engagement in this field (Fresko, Kfir, \& Nasser, 1997). The motives connected to this issue also occur in literature on pedagogy and psychology. The higher performance might be achieved via extrinsic motivation, it is only for a short term, though. The worst relation is also between motivation and a specific activity (Klein, 2006). Extrinsic motives in teaching career are undesirable because dissatisfaction in performance may be shown in the teachers' workplace, as well as in their actions (Fresko, Kfir, \& Nasser, 1997). We have registered the following extrinsic motives in pedagogical and psychological literature: the desire to have steady income (Saban, 2003), a stable working place after studies (Papanastasiou \& Papanastasiou, 1997), holidays (Kyriacou, Hultgren, \& Stephens, 1999), job security (Johnston, McKeown \& McEwen, 1999), more time for family and children (Watt \& Richardson, 2007), and teaching career prestige in the society (Bastick, 1999). Altruistic motivation plays an important role when choosing teaching as a career. The altruistic motive may be understood as the desire to improve the well-being of other people (Klein, 2006). It is connected with the concept of prosociality and it covers doing things intentionally to help another person or a group of people. The altruistic motives are closely related to intrinsic motives because they correspond with the career content (Kyriacou \& Hultgren, 2000; Kyriacou, Hultgren, \& Stephens, 1999; Saban, 2003). 


\section{Research Problem}

As already mentioned in the text above, specific motives implemented in the final version of the SMVUP (SMVUP-4-S) model are based on theoretical origins and empirical findings of Slovak and foreign authors (e.g. Book \& Freeman, 1986; Lortie, 1975; Robertson, Keith, \& Page, 1983; Watt, Richardson, \& Pietsch, 2013; Hřebíček, 1995; Kasáčová, 1996; Kariková, 2004; Schutz, Crowder, \& White, 2001; etc.). Types of motivation for choosing teaching as a career in previous research and studies can be mapped as the main design of the SMVUP-S scale. From the previous theoretical circuits and empirical evidence in the field of teacher motivation, the scale indicated the existence of 11 types of motivation for the choice of the teaching profession, which were divided into three basic theoretical circuits:

- Intrinsic motivation: interest, self-perception of teaching skills, work potential and previous experience;

- Extrinsic motivation: benefits, income, social status and significant others;

- Altruistic motivation: prosocial behavior, work with children and work with youth.

Given that in SMVUP-3-S model, final adjustments were made (content correction, items correction, factors differentiation), the aim of the research was to verify the construct validity of the SMVUP-4-S assessment tool, specifically: a) to measure the correlation between the individual subscales of an assessment tool; $b$ ) to determine the reliability of the individual subscales of an assessment tool and its main constructs; c) to identify the internal consistency using EFA and CFA analyzes.

\section{Research Methodology}

\section{General Characteristics}

The aim of the research was to verify the construct validity of the SMVUP-4-S assessment tool. This aim involved measuring the psychometrics characteristics of the assessment tool. In order to achieve this aim, quantitative oriented research was carried out, which allowed the use of statistical procedures to measure validity and reliability of the assessment tool. Data were collected by the psychologists at Slovak universities (paper form). All questionnaires were anonymous, and participants submitted completed questionnaires with the consent to process the data. The participants had approximately 45 minutes to complete the questionnaire. The final version of the assessment tool was elaborated in March - April 2016. The data were collected during three academic years: September 2016, September 2017 and September 2018. In January 2019 the data were processed and analyzed.

\section{Research Sample}

The research sample consisted of the Slovak university students (Catholic University Ružomberok, Comenius University, Constantine the Philosopher University, DTI University, Matej Bel University, University of Prešov, University of Trnava, University of Žilina) from all the regions in Slovakia (Nitra, Bratislava, Banská Bystrica, Prešov, Trenčín, Trnava and Žilina). In total, 1235 students in the first year of bachelor studies were involved in the research (teacher trainee students). A research sample consists of 478 male and 722 female respondents (35 uncategorized), with an average age of 20.10 years. In the academic year 2015/2016 3300 adolescents were admitted into their first year of study. According to the approximation of Morgan and Krejcie (1970), at least 1066 respondents must be included in the set, with a percentage distribution corresponding to the size of the basic set in each region (confidence 99.00\%, Margin of Error 3.50\%). During the research, 1500 questionnaires were distributed, 
Robert TOMŠIK. Choosing teaching as a profession: Validation of an SMVUP-4-s assessment tool

PROBLEMS

OF EDUCATION

IN THE $21^{\text {st }}$ CENTURY

Vol. 77, No. 4, 2019

548

which means that the return of the questionnaires was $82.34 \%$. This means that criterion of Morgan and Krejcie approximation was fulfilled. The choice of the first-year students was based on the assumption that there was a primary motivation for choosing teaching as a career. The primary motivation of the students in the following years might be modified due to other factors. In order to perform the EFA and the subsequent CFA, the entire set was first randomly split into two datasets: $n_{1}=617$ (determined for EFA) and $n_{2}=618$ (determined for CFA). The resulting half did not show any significant differences from the total dataset or between other datasets in terms of gender, country, or age.

\section{Instrument and Procedures}

The Scale of Motivation for Choosing a Teaching Profession (fourth re-edition, version for students (S); thereinafter SMVUP-4-S) is a research and diagnostic tool for identifying the motives for choosing a teaching as a profession. The SMVUP-4-S scale was based on the globally used Fit-Choice scale (Watt \& Richardson, 2012), which was adapted to the conditions of the profession and educational system of the Slovak Republic. Following the agreement of the authors of the Fit-Choice model, the scale was translated into Slovak language and subsequently translated by different translators into English. Based on several validations (Tomšik \& Verešová, 2015; Tomšik, 2016a, Tomšik, 2016c) of the internal consistency and validity of the model, the final, fourth re-edition of the SMVUP model was developed for the teacher trainee students. This model consists of three scales that are saturated with the following factors:

- Intrinsic motivation: interest, self-perception of teaching skills, work potential, previous experience;

- Extrinsic motivation: benefits, income, social status, significant others;

- Altruistic motivation: prosocial behavior, work with children, work with youth.

Each subscale consists of four items. The items of the range are in the form of assertions that the respondents answer on a 5-point Likert scale. The score of the respondents can range from 4 points as a minimum score to 20 points as a maximum score. The higher score represents a higher level of motivation factor.

\section{Data Analysis}

The data were processed using the SPSS v. 20, and module SPSS AMOS v. 22. Several methods of descriptive statistics (number, minimum, maximum, average and standard deviation) were used for data description and Spearman's rho coefficient for measuring correlation between SMVUP model's variables. The normality of data distribution was estimated using skewness and kurtosis, and Kolmogorov-Smirnov test. When testing the psychometric characteristics of an assessment tool, the following tests were applied:

- Cronbach's alpha to measure internal consistency of an assessment tool.

- Exploratory factor analysis (EFA) was used for factor structure identification of an assessment tool based on Kaiser-Meyer-Olkin criterion using Principal component method (extraction based on Eigenvalues $>1$ and Scree plot).

- Confirmatory factor analysis (CFA) was used to determine parameters of extracted factors using Maximum Likelihood method. For detecting degrees of consistency of predicted models following statistical procedures chi-square goodness of fit test $\left(\chi^{2}\right)$, chi- square to degrees of freedom ratio $\left(\chi^{2} / \mathrm{df}\right)$, CFI (Comparative Fit Index), TLI (Tucker Lewis Index), RMSEA (Root Mean Square Error of Approximation) and SRMR (Standardized Root Mean Square Residual) were used. To estimate the relative quality of statistical models Akaike information criterion (AIC) and Bayesian information criterion (BIC) were used. 


\section{Research Results}

\section{Descriptive Results}

Table 1 shows the basic descriptive results of the scores of each SMVUP subscale and the results of the correlation analysis (Spearman's correlation coefficient) among all variables of SMVUP model $(N=1235)$. The minimum score for all variables was 4 points, and the maximum score in the vast majority of the variables was 20 points (except for the variable Social status MAX = 19). Spearman's correlation coefficient revealed significant correlations within individual subscales. Correlations were significant at .01 of statistical significance. Several significant correlations at a level of statistical significance of .05 and .01 were also found between variables that were not covered by the same scale. As the part of the data description, the normality of data distribution was also measured. In two variables, negative kurtosis was found above $>-1(\mathrm{MIN} \gamma 2=.008, \mathrm{MIN} \gamma 2=-1.087, \mathrm{SE}=.243)$. The skewness of data ranged within $\pm 1(\mathrm{MIN} \gamma 1=.166$, MIN $\gamma 1=-.365$, SE = .122). Nevertheless, the hypothesis on the normality of data distribution was refuted based on the results of Kolmogorov-Smirnov test, the KS test values in all variables were significant at the level of statistical significance of .001.

Table 1. Descriptive results of SMVUP subscales and Pearson correlation coefficients between subscales $(N=1235)$.

\begin{tabular}{|c|c|c|c|c|c|c|c|c|c|c|c|c|}
\hline & & 1 & 2 & 3 & 4 & 5 & 6 & 7 & 8 & 9 & 10 & 11 \\
\hline$M$ & & 13.25 & 14.78 & 14.64 & 11.02 & 9.91 & 11.89 & 10.38 & 10.90 & 14.62 & 12.47 & 14.47 \\
\hline$S D$ & & 4.418 & 3.210 & 3.389 & 4.888 & 3.586 & 3.535 & 3.786 & 4.727 & 4.504 & 4.264 & 3.155 \\
\hline 1 & Interest & 1 & & & & & & & & & & \\
\hline 2 & $\begin{array}{l}\text { Self-perception of } \\
\text { teaching skills }\end{array}$ & $.461^{\prime \prime}$ & 1 & & & & & & & & & \\
\hline 3 & Work potential & .322 & $.436 "$ & 1 & & & & & & & & \\
\hline 4 & Previous experience & $.329^{\prime *}$ & $.392^{\prime *}$ & $.143^{* \prime}$ & 1 & & & & & & & \\
\hline 5 & Social status & .092 & -.043 & -.006 & $.147^{\prime \prime}$ & 1 & & & & & & \\
\hline 6 & Benefits & $.134^{\prime \prime}$ & .024 & -.016 & .022 & $.353^{* *}$ & 1 & & & & & \\
\hline 7 & Income & $.147^{*}$ & .006 & .008 & $.228 "$ & $.530^{\circ *}$ & $.401{ }^{\prime \prime}$ & 1 & & & & \\
\hline 8 & Significant others & $-.197^{* \prime}$ & $-.275^{\prime \prime}$ & $-.255^{\prime \prime}$ & .091 & $.099^{*}$ & $.100^{\circ}$ & $.144^{\prime \prime}$ & 1 & & & \\
\hline 9 & Work with children & $.451^{*}$ & $.381^{*}$ & $.382^{\prime *}$ & $.156^{* \prime}$ & $-.154^{\prime \prime}$ & -.020 & -.060 & -.164 & 1 & & \\
\hline 10 & Work with youth & .097 & $.253^{\prime \prime}$ & $.293^{*}$ & .038 & -.002 & . 046 & $.123^{*}$ & -.064 & $.436^{* *}$ & 1 & \\
\hline 11 & Prosocial behavior & $.166^{* \prime}$ & $.448^{* *}$ & $.602 *$ & .073 & -.013 & $.121^{*}$ & $.103^{*}$ & $-.101^{*}$ & .294" & $.448^{\prime \prime}$ & 1 \\
\hline
\end{tabular}

$* p<.05, * * p<.01, N-$ number; $M$ - average; $S D-$ standard deviation. 
Robert TOMŠIK. Choosing teaching as a profession: Validation of an SMVUP-4-s assessment tool

PROBLEMS

OF EDUCATION

IN THE $21^{\text {st }}$ CENTURY

Vol. 77, No. 4,2019

550

\section{Exploratory Factor Analysis}

Exploratory factor analysis was used to identify individual factors (EFA, Principal component analysis, statistical program SPSS ver. 22) on a sample of 617 students. EFA was applied to each scale of SMVUP model (Intrinsic, Extrinsic and Altruistic motivation). Prior to the EFA application, the test application criterion was tested using the Kaiser-Meyer-Olkin test. The results show that our data meet the conditions for using factor analysis (Intrinsic KMO = $.801, \mathrm{KMO}$ Extrinsic $\mathrm{KMO}=0.794$, Altruistic $\mathrm{KMO}=.830$ ). The Eigenvalues (Table 1 ) were used to select the final number of factors for the SMVUP-4-S tool. The Eigenvalues show that it is realistic to consider the four factors in the scales Intrinsic and Extrinsic motives and three factors in the Altruistic motives scale. Using the analysis, eleven factors were extracted having values $>1$. The factor loading of the individual factors is summarized in Table 2 . The only items that have loadings above the level .350 were included in the factors. However, neither item had a factor loading below the given value, so neither item was eliminated. The Intrinsic motivation explained approximately $54.195 \%$ of the variability in the examined dataset, the model of the Extrinsic motivation explaining approximately $52.551 \%$ of the variability in the examined dataset, and the Altruistic motivation explained approximately $60.476 \%$ of the variability in the examined dataset. 
Table 2. Summarized Factor Matrix and Initial Eigenvalues.

PROBLEMS

OF EDUCATION

IN THE $21^{\text {st }}$ CENTURY

Vol. 77, No. 4, 2019

551

\begin{tabular}{|c|c|c|c|c|c|c|}
\hline \multirow{2}{*}{ Scale } & \multirow{2}{*}{ Factor } & \multirow{2}{*}{ Item } & \multirow{2}{*}{ Loadings } & \multicolumn{3}{|c|}{ Initial Eigenvalues } \\
\hline & & & & Total & $\%$ of Variance & Cumulative $\%$ \\
\hline \multirow{16}{*}{ 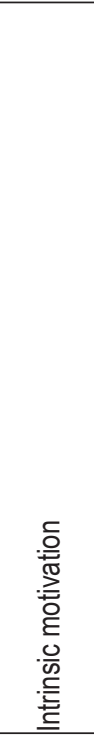 } & \multirow{4}{*}{ Interest } & A1 & .901 & \multirow{4}{*}{2.341} & \multirow{4}{*}{14.632} & \multirow{4}{*}{14.632} \\
\hline & & A3 & .663 & & & \\
\hline & & A4 & .398 & & & \\
\hline & & A5 & .571 & & & \\
\hline & \multirow{4}{*}{ Self-perception of teaching skills } & $\mathrm{B} 1$ & .475 & \multirow{4}{*}{2.176} & \multirow{4}{*}{13.600} & \multirow{4}{*}{28.233} \\
\hline & & $\mathrm{B} 2$ & .753 & & & \\
\hline & & B3 & .654 & & & \\
\hline & & B4 & .735 & & & \\
\hline & \multirow{4}{*}{ Work potential } & $\mathrm{J} 1$ & .677 & \multirow{4}{*}{2.170} & \multirow{4}{*}{13.564} & \multirow{4}{*}{41.797} \\
\hline & & J3 & .731 & & & \\
\hline & & $\mathrm{J} 4$ & .634 & & & \\
\hline & & $\mathrm{J} 2$ & .652 & & & \\
\hline & \multirow{4}{*}{ Previous experience } & $\mathrm{N} 1$ & .511 & \multirow{4}{*}{1.984} & \multirow{4}{*}{12.398} & \multirow{4}{*}{54.195} \\
\hline & & N2 & .677 & & & \\
\hline & & N3 & .705 & & & \\
\hline & & N4 & .738 & & & \\
\hline \multirow{16}{*}{ 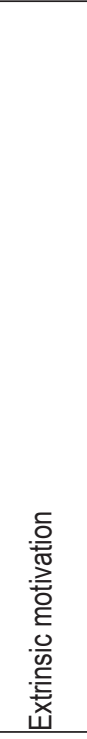 } & & $\mathrm{C} 1$ & .377 & & & \\
\hline & Sorial ctatus & $\mathrm{C} 2$ & .761 & 2517 & 15018 & 15018 \\
\hline & soclal status & C3 & .831 & 2.541 & 15.918 & 15.918 \\
\hline & & $\mathrm{C} 4$ & .726 & & & \\
\hline & & D1 & .421 & & & \\
\hline & & D2 & .613 & & & \\
\hline & Benefits & D3 & .770 & 1.992 & 12.451 & 28.310 \\
\hline & & D4 & .726 & & & \\
\hline & & E1 & .589 & & & \\
\hline & Income & E2 & .414 & 1975 & 12346 & 40716 \\
\hline & Income & E3 & .651 & 1.915 & 12.340 & 40.110 \\
\hline & & E4 & .841 & & & \\
\hline & & $\mathrm{H} 1$ & .591 & & & \\
\hline & Sianificant otherc & $\mathrm{H} 2$ & .872 & 1894 & 11835 & 52551 \\
\hline & sigmintiantiluts & $\mathrm{H} 3$ & .780 & 1.094 & 11.000 & 02.001 \\
\hline & & $\mathrm{H} 4$ & .769 & & & \\
\hline & & $\mathrm{F} 1$ & .745 & & & \\
\hline & Whor with shildron & $\mathrm{F} 2$ & .722 & 2004 & 22360 & 22360 \\
\hline & vark witn crilaren & F3 & .842 & 2.804 & 23.300 & 23.300 \\
\hline & & $\mathrm{F} 4$ & .806 & & & \\
\hline & & $\mathrm{G} 1$ & .853 & & & \\
\hline & Work with vouth & G2 & .592 & 2527 & 21058 & 44.66 \\
\hline & vvork witn youtn & G3 & .859 & 2.521 & 21.058 & $44.4 \angle 0$ \\
\hline 등 & & G4 & .861 & & & \\
\hline i & & $\mathrm{J} 1$ & .646 & & & \\
\hline$\frac{E}{E}$ & & $\mathrm{~J} 2$ & .679 & 1926 & & \\
\hline 을 & Prosocial behavior & J3 & .592 & 1.926 & 16.051 & $60.4 / 6$ \\
\hline$\frac{\underline{\underline{L}}}{\frac{2}{2}}$ & & $\mathrm{~J} 4$ & .729 & & & \\
\hline
\end{tabular}


Robert TOMŠIK. Choosing teaching as a profession: Validation of an SMVUP-4-s assessment tool

PROBLEMS

OF EDUCATION

IN THE $21^{\text {st }}$ CENTURY

Vol. 77, No. 4, 2019

552

\section{Confirmatory Factor Analysis}

A three-scale model was subjected to Confirmatory Factor Analysis (CFA). The specific intention was to verify the multifactor solution of the individual SMVUP models in the second half of the research file $(\mathrm{n} 2=681)$. CFA was applied using the IMB SPSS ver. 20 using the IBM SPSS AMOS ver. 22. The first scale of the SMVUP model was called Intrinsic motivation, which consists of 16 items accumulated in 4 subscales: Interest, Self-perception of teaching skill, Work potential and Previous experience. The base model without modifications showed the following values: $\chi^{2}(95)=467.894, p<.001$, RMSEA $=.099, \mathrm{SRMR}=.079, \mathrm{CFI}=.865$, $\mathrm{TLI}=.830$ (Figure 1$)$.

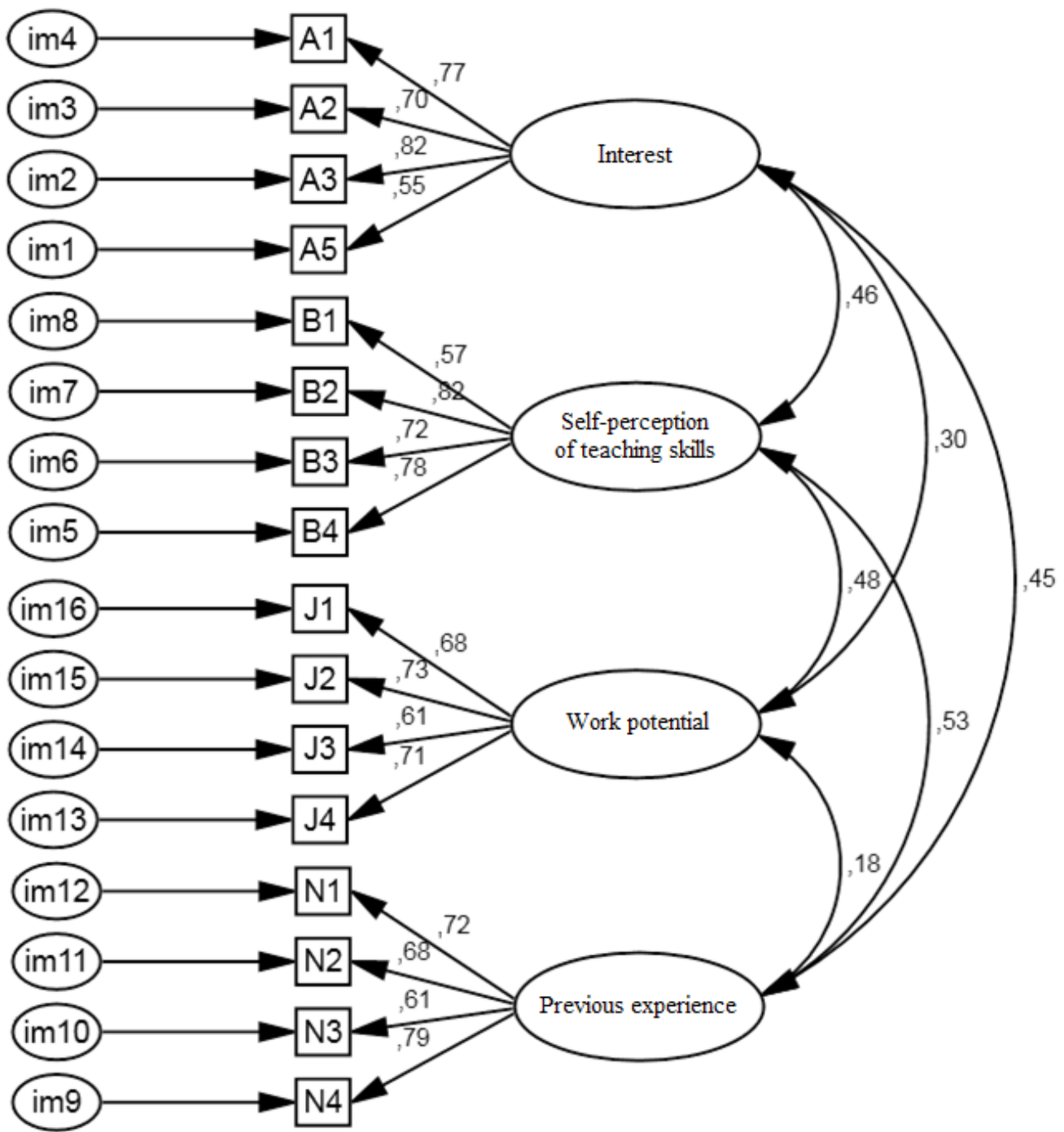

Figure 1. CFA scheme of Scale Intrinsic Motivation of SMVUP model.

Likewise, the second scale of the SMVUP model is called Extrinsic motivation, which consists of 16 items accumulated in 4 subscales: Social status, Benefits, Income and Significant others. The base model without modifications showed the following values: $\chi^{2}(98)=477.545$, $p<.001, \mathrm{RMSEA}=.097, \mathrm{SRMR}=.075, \mathrm{CFI}=.847, \mathrm{TLI}=.813$ (Figure 2 ). 


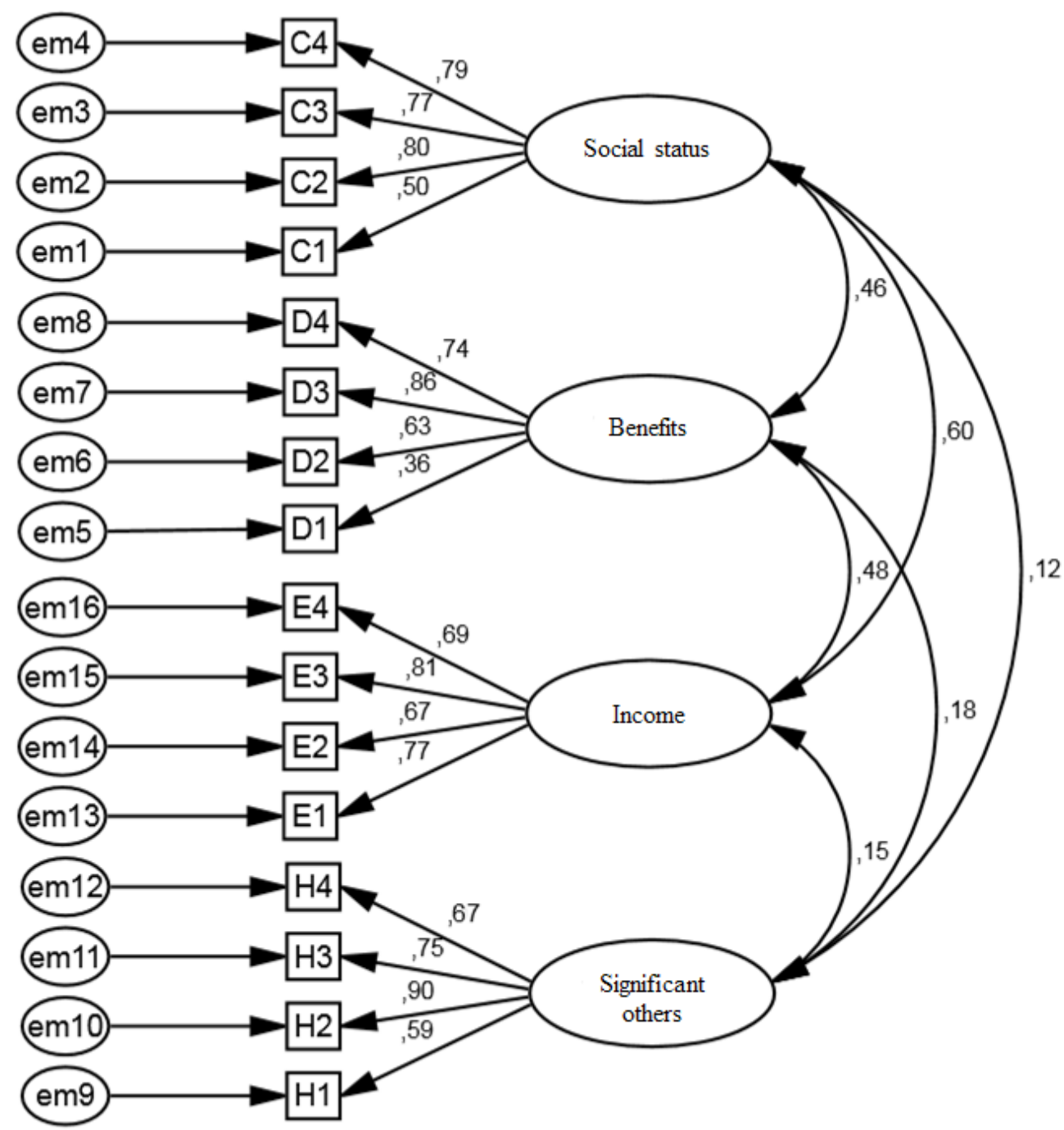

Figure 2. CFA scheme of Scale Extrinsic Motivation of SMVUP model.

In the last scale defined as Altruistic motivation, modifying indexes show that several items have correlated residual variance. These items formed logical three couples that had a similar formulation but were focused on measurement different factor within the Altruistic motivation scale. G1: I like working with youth / F1: I like working with children; G2: I want a profession that involves working with youth / F2: I want a profession that involves working with children; G3: I want to work in an environment with youth / F3: I want to work in an environment with children. This model converged normally after 32 iterations and showed the following data compliance metrics: $\chi^{2}(46)=216.913, p<.001$, RMSEA $=.096$, SRMR $=.074, \mathrm{CFI}=.934, \mathrm{TLI}=.906$ (Figure 3 ). In all the cases, the RMSEA indicator appears as a problem, because $\chi^{2}$ statistics is affected by a sample size and also deviations from normal distribution (Hooper, Coughlan, \& Mullen, 2008). However, values $\chi^{2} / d f>5.0$ indicate that the ratio is satisfactory (Table 3 ). EFA and CFA results contribute to the validity of the SMVUP-4-S assessment tool. 
PROBLEMS

OF EDUCATION IN THE $21^{\text {st }}$ CENTURY Vol. 77, No. 4, 2019

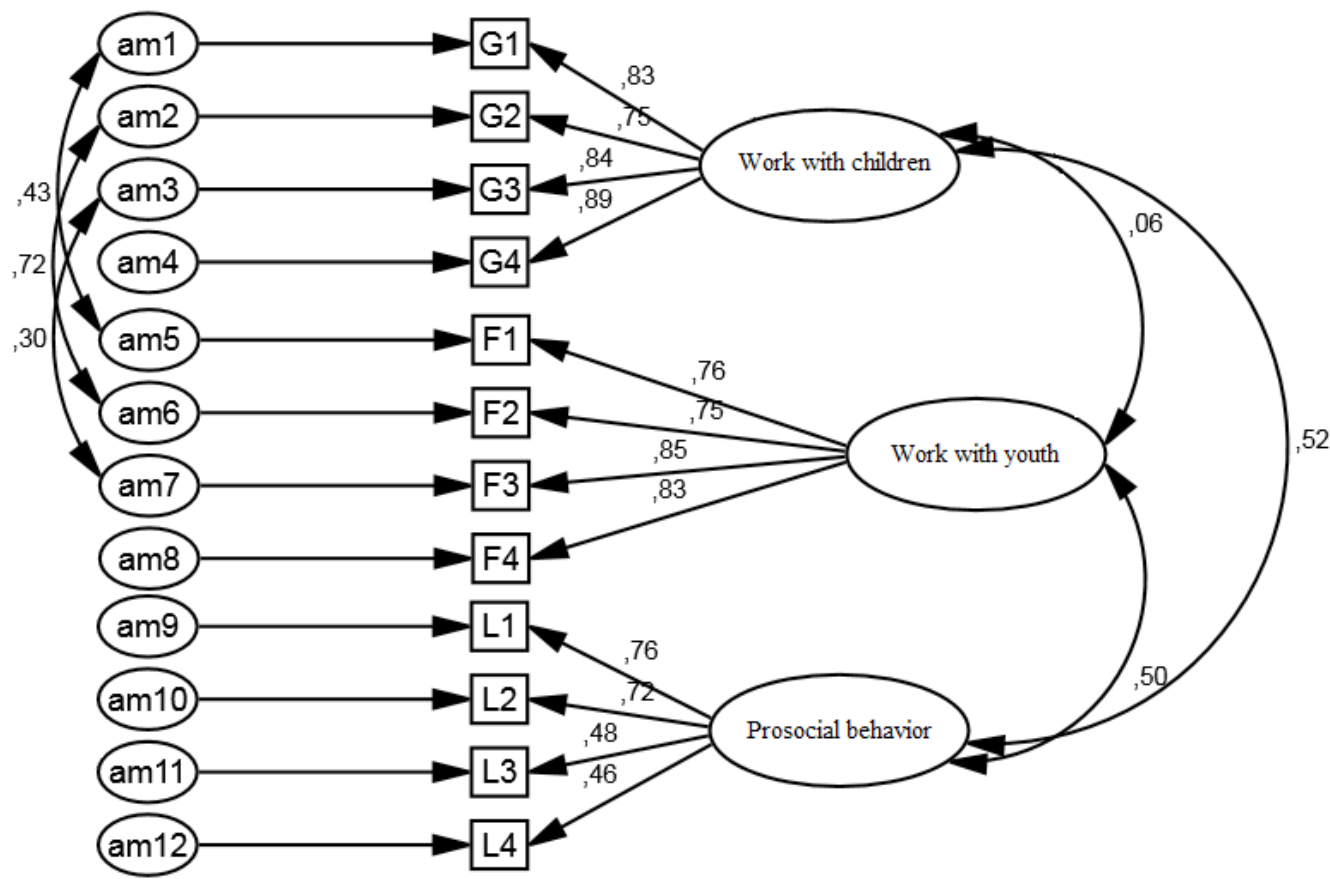

Figure 3. CFA scheme of Scale Altruistic Motivation of SMVUP model.

Table 3. Validate the suitability of the resulting Factor Models of the SMVUP tool using the selected parameters.

\begin{tabular}{lccccccccc}
\hline Model & $\chi^{2}$ & $d f$ & $p$ & $\chi^{2}$ ldf & CFI & RMSEA & SRMR & AIC & BIC \\
\hline Intrinsic motivation & 467.894 & 95 & .001 & 4.925 & .865 & .099 & .079 & 549.894 & 713.749 \\
\hline Extrinsic motivation & 477.545 & 98 & .001 & 4.781 & .847 & .097 & .075 & 544.540 & 696.406 \\
\hline Altruistic motivation & 714.569 & 54 & .001 & 13.233 & .747 & .175 & .182 & 762.569 & 858.484 \\
\hline Altruistic motivation RE & 216.913 & 46 & .001 & 4.715 & .934 & .096 & .074 & 28.913 & 408.799
\end{tabular}

Notes: $R E=$ modified model by adding covariance between items, $\chi^{2}=$ chi-square, $d f=$ degrees of freedom, $p=$ significance level, $C F I=$ Comparative Fit Index, RMSEA = Root Mean Square Error of Approximation, SRMR = Standardized Root Mean Square Residual, AIC = Akaike information criterion, BIC = Bayesian information criterion.

\section{Internal Consistency}

Within this research, the reliability of the whole assessment tool and its individual subscales was measured by calculating the Cronbach alpha coefficient. The Cronbach alpha coefficient at the subscales ranged from $\alpha=.705$ to $\alpha=.891$, while for the scale Intrinsic motivation was $\alpha=.843$, for the scale Extrinsic motivation was $\alpha=.833$, and for the scale Altruistic motivation was $\alpha=.818$. The versions constructed on the basis of the exploratory factor analysis were saturated with a total of eleven subscales that together had a Cronbach alpha coefficient of $\alpha=.843$. Within the scale Intrinsic motivation, to individual subscales the 
following alpha values were measured: Interest $\alpha=.778$, Self-perception of teaching skills $\alpha=.851$, Work potential $\alpha=.783$, Previous experience $\alpha=.791$; Within the scale External motivation: Social status $\alpha=.802$, Benefits $\alpha=.742$, Income $\alpha=.824$, Significant others $\alpha=$ 0.891; and within the scale Altruistic motivation: Working with children $\alpha=.866$, Work with youth $\alpha=.833$, Prosocial behavior $\alpha=.818$. The Alpha coefficient of the individual subscales was high $(\alpha>.8)$, or satisfying $(\alpha>.7)$, suggesting that none of the subscales was considered as an issue in terms of internal consistency.

\section{Discussion}

The aim of this research was to verify the psychometric characteristics of the Slovak questionnaire SMVUP-4-S, namely the fourth reedition of the Scale of motivation for choosing teaching profession. Due to the necessity of the situation (system of education in the Slovak Republic and topicality of this issue) the SMVUP model (based on self-termination theory and work motivation) was created, however, lacking validation findings of the model. Despite the fact that we register validated research instruments for measuring motivation of teaching career (e.g. FIT-Choice scale, Watt \& Richardson, 2007; Orientation for Teaching Survey (OTS), Simić, Purić, \& Stančić, 2018; The Attractors and Facilitators for Physical Education Questionaerie (AFPE), Spittle, Jackson, \& Casey 2009), some validation studies had problems to adjust stated models to European conditions. As for example Fokkens-Bruinsma, Canrinus, Korpershoek, and Doolaard (2015), Gratacós and Puig (2016), Nesje, Brandmo, and Berger (2017), Rothland (2013) etc. in which the content of the profession and the school system is different from the content of the profession through which these scales were construed (America, Oceania). The following problems were found through validation process: translations of items, factor structure (Brandamo \& Berger, 2017); construct validity and reliability, factor loadings, cultural differences (Nesje, Brandmo, \& Berger, 2017), factor loadings, cultural differences (Hennessy \& Lynch, 2017).

In comparison with FIT-Choice scale, SMVUP model does not contain items and factors focused on measurement as this is not typical for the schooling system in the middle of Europe, and therefore it is irrelevant to measure these variables. Thus, it is impossible to measure adequately the motivation in the choice of a teaching career as this can lead to incorrect results despite the facts that these studies measuring motivation of teaching career choice (cf. Nesje, Brandmo, \& Berger, 2017) enable comparison in the rating of identified (similar and different) motives in different demographical environments. Nevertheless, SMVUP model describes well the conditions of the education and teaching profession not only in Slovakia and as it was found out by this study, it shows satisfactory psychometric characteristics: questionnaire was characterized by a high internal consistency in all three scales of the SMVUP model: intrinsic $(\alpha=.94)$, extrinsic $(\alpha=.94)$ and altruistic motivation $(\alpha=.94)$. Thus, we can deduce that neither one of the subscales of SMVUP model is problematic in terms of reliability. Indicators of empirical validity of this model are also researches carried out using SMVUP-4-S scale (and its reeditions). The following research facts were found with the use of this scale: gender differences (Tomšik, 2015), the differences with regard to study programs (Tomšik \& Čerešník, 2017), demographic and geographical differences (Tomšik, 2016d), correlation with the questionnaire NEO-FFI (Tomšik \& Gatial, 2018; Tomšik, 2018a), and DZSV questionnaire (Tomšik, 2018b), satisfaction with the choice of profession (Tomšik, 2016b) and time-dependent reliability was also investigated and satisfactory results were found (Tomšik, 2016a).

Confirmatory factor analysis supported the assumption of the three-factor structure of the SMVUP model, which assumes the influence of three types of motivation on the choice of the teaching profession (intrinsic, extrinsic and altruistic). The subscales showed high factorial saturation, and each of the 11 extracted factors consists of 4 items. The individual extracted factors are defined as follows:

\begin{tabular}{|l} 
PROBLEMS \\
OF EDUCATION \\
IN THE 21 $1^{\text {st }}$ CENTURY \\
Vol. 77, No. 4, 2019
\end{tabular} 
Robert TOMŠIK. Choosing teaching as a profession: Validation of an SMVUP-4-s assessment tool

PROBLEMS

OF EDUCATION

IN THE $21^{\text {st }}$ CENTURY

Vol. 77 , No. 4, 2019

556

A. Factor structure of the scale Intrinsic motivation: Factor 1: Interest (Self-perception of the preference, interest and inner value of the teaching profession); Factor 2: Previous experience (The rate of practical teaching experience); Factor 3: Selfperception of teaching skills (Self-perception of the readiness of respondents towards the teaching profession. Level of capability); Factor 4: Work potential (Selfperception of the rate of interest in working with children);

B. Factor structure of the scale Altruistic motivation: Factor 5: Working with children (Self-perception of the rate of interest in working with children); Factor 6: Working with youth (Self-perception of the rate of interest in working with youth); Factor 7: Prosocial behaviour (The extent to which the individual is willing to centre their profession in favour of their students);

C. Factor structure of the scale Extrinsic motivation: Factor 8: Benefits (Individual's view on how the teaching profession is socially awarded. Choosing the profession because of social prestige); Factor 9: Social status (Concept of positive and negative factors of teaching profession according to the individual's perspective. Calculation of the importance of positive factors related to the teaching profession (e.g., school holidays)); Factor 10: Income (Perception of the importance of income in the teaching profession); Factor 11: Significant others (Impact of significant others on decision to choose teaching as a profession).

In addition to the satisfactory EFA (factor saturation $>.300$ ) and CFA results $\left(\chi^{2} / \mathrm{df}<\right.$ 5.0 , RMSEA $<1$, SRMRS $<.8$ ), which suggests a good internal validity of SMVUP model, we also highlight the results of the correlation analysis - most factors from the Intrinsic motivation scale were correlated with factors from the Altruistic motivation scale, namely: Interest in Work with children and Prosocial behaviour, Self-perception of teaching skills and Work potential with all factors of the scale Altruistic motivation; and Previous experience with Work with children. Also, positive and negative statistically significant correlations were found between scales Intrinsic and Altruistic motivation and motives of the Extrinsic motivation scale, for example: Significant others correlated negatively with almost all the motives of Intrinsic and Altruistic motivation scales; Work with children correlated negatively with Social status; or Income with previous experience.

\section{Conclusions}

Based on the results of this research, it can be concluded that the SMVUP-4-S questionnaire has acceptable psychometric characteristics. Based on the three-step access to psychometric verification, including correlation analysis, reliability, second order confirmation factor analysis, the final measurement construct with 44 entries is validated. Concluding these findings, theoretical and methodological issues are discussed in relation to the application of the organizational innovation construct. Regarding the fact that psychometric characteristics of the research instrument are satisfactory, the scale is possible to be used for measurement the motivation for teaching career with the fact that the results received through this research instruments are reliable. SMVUP model and the research instrument is the only validated instrument for measuring the motivation for choosing the teaching career in Slovakia and in comparison with the other already validated models in the USA or Oceania, it has been adjusted to the conditions of the education in the Middle Europe. The prospective aim is thus to implement also other motives into the model, such as Idols (teacher influences) stated in the literature as a significant intrinsic motive of the teaching career choice. Another intention is to adapt the research instrument to other social and cultural specifications or translation into other languages. This form of cooperation with the foreign experts could help in measuring the motivation of the teaching career choice in other conditions and enable the comparison 
of motives as well as the prediction in directing the education and personal (motivational) specifications of undergraduate students in teaching programs. Following this research intention should enable not only to predict the development of education at universities but also the findings of attractive/unattractive factors of the teaching profession. Thus, the universities would be able to get the feedback on the facts which prevent students from choosing teaching career and that would enhance them to work on weaknesses of the profession and eventually make possibilities in making it more attractive.

\section{References}

Bastick, T. (1999). A motivation model describing the career choice of teacher trainees in Jamaica. In Biannual conference of the international study association in teachers and teaching, (pp. 1-9). Dublin: Ireland.

Book, C. L., \& Freeman, D. J. (1986). Differences in entry characteristics of elementary and secondary teacher candidates. Journal of Teacher Education, 37, 47-51.

Brown, M. M. (1992). Caribbean first-year teachers' reasons for choosing teaching as a career. Journal of Education for Teaching, 18, 185-195.

Eccles, J. S., \& Wigfield, A. (2002). Motivational beliefs, values, and goals. Annual Review of Psychology, 53, 109-132.

Fokkens-Bruinsma, M., Canrinus, E.T., Korpershoek, H., \& Doolaard, S. (2015). Motivation for becoming a teacher. Validation of the FIT-Choice Scale for the Dutch context. Pedagogische Studien, 92(5), 324-343.

Fresko, B., Kfir, D., \& Nasser, F. (1997). Predicting teacher commitment. Teaching and Teacher Education, 13, 429-438.

Gratacós, G., \& Puig, M. L. J. (2016). Validation of the Spanish version of the Factors Influencing Teaching (FIT)-Choice scale. Revista de Educacion, 2016 (372), 87-105.

Hennessy, J., \& Lynch, R. (2017). "I chose to become a teacher because". Exploring the factors influencing teaching choice amongst pre-service teachers in Ireland. Asia-Pacific Journal of Teacher Education, 45(22), 106-125.

Holland, J. L. 1985. Vocational preference inventory manual. Odessa: Psychological Assessment Resources.

Hřebíček, L. (1995). Professional development of teachers. Pedagogická orientace, 17, 70-77.

Johnston, J., McKeown, E., \& McEwen, A. (1999). Choosing primary teaching as a career: The perspectives of males and females in training. Journal of Education for Teaching, 25, 55-64.

Joseph, P. B., \& Green, N. (1986). Perspectives on reasons for becoming teachers. Journal of Teacher Education, 37, 28-33.

Kariková, S. (2004). Špecifiká profesijnej dráhy učiteliek [The specifics of the career of teachers]. Prešov: MPC.

Kasáčová, B. (1996). Očakávania a predstavy študentov učitel’stva 1. stupňa ZŠ a ich postoje k pedagogicko-psychologickej príprave [Expectations and ideas of primary school teachers and their attitudes to pedagogical-psychological preparation to teach]. Pedagogická revue, 48, 311317.

Klein, V. (2006). Motivation for lifelong learning. Žilina: Euroformes.

Kyriacou, C., \& Coulthard, M. (2000). Undergraduates' views of teaching as a career choice. Journal of Education for Teaching, 26, 117-126.

Kyriacou, C., Hultgren, A., \& Stephens, P. (1999). Student teachers' motivation to become a secondary school teacher in England and Norway. Teacher Development, 3, 373-381.

Liu, E., Kardos, S. M., Kauffman, D., Peske, H. G., \& Johnson, S. M. (2000). Barely breaking even: Incentives, rewards, and the high costs of choosing to teach. Harvard, UK: Harvard Graduate School of Education.

Lortie, D. C. (1975). School teacher: A sociological study. Chicago: University of Chicago Press.

Morgan, D. W., \& Krejcije, R. V. (1970). Determining sample size for research activities. Educational and Psychological Measurement, 30, 607-610

\author{
PROBLEMS \\ OF EDUCATION \\ IN THE $21^{\text {st }}$ CENTURY \\ Vol. 77, No. 4, 2019 \\ 557
}


Robert TOMŠIK. Choosing teaching as a profession: Validation of an SMVUP-4-s assessment tool

PROBLEMS

OF EDUCATION

IN THE $21^{\text {st }}$ CENTURY Vol. 77 , No. 4, 2019

558

Nesje, K., Brandmo, C., \& Berger, J-L. (2017). Motivation to become a teacher: A Norwegian validation of the factors influencing teaching choice scale. Scandinavian Journal of Educational Research, $17,2-19$.

Papanastasiou, C., \& Papanastasiou, E. (1997). Factors that influence students to become teachers. Educational Research and Evaluation, 3, 305-316.

Robertson, S., Keith, T., \& Page, E. (1983). Now who aspires to teach? Educational Researcher, 12, 1321.

Rothland, M. (2013). "Riskante" Berufswahlmotive und Überzeugungen von Lehramtsstudierenden ["Risky" career choices and beliefs of teacher trainees]. Erziehung \& Unterricht, 163(1/2), 71-80

Ryan, R. M., \& Deci, E. L. (2000). Intrinsic and extrinsic motivations: Classic definitions and new directions. Contemporary Educational Psychology, 25(1), 54-67.

Saban, A. (2003). A Turkish profile of prospective elementary school teachers and their views of teaching. Teaching and Teacher Education, 19, 829-846.

Schutz, P. A., Crowder, K. C., \& White, V. E. (2001). The development of a goal to become a teacher. Journal of Educational Psychology, 93, 299-309.

Simić, N., Purić, D., \& Stančić, M. (2018). Motivation for the teaching profession: Assessing psychometric properties and factorial validity of the Orientation for Teaching Survey on in-service teachers. Psihologija, 51, 1-23.

Spittle, M., Jackson, K., \& Casey, M. (2009). Applying self-determination theory to understand the motivation for becoming a physical education teacher. Teaching and Teacher Education, 25, 190197.

Tomida, J., \& Miwa, S. (2018). Examining predictive Validity of FIT-Choice Scale in Japanese undergraduates. In International Conference on Psychology, Language and Teaching, Proceedings of 187th The IIER International Conference (pp. 26-28). Hong Kong: International Institute of Engineers and Researchers.

Tomšik, R. (2015). Gender differences in motivations for choosing teaching as a career. In Evropské pedagogické fórum 2015: př́nosy, výzvy, očekávání. Sborník z mezinárodní vědecké konference, (pp. 130-137). Hradec Králové : Magnanimitass.

Tomšik, R., \& Verešová M. (2015). Škála motivácie vol’by učitel'ského povolania [Scale of Motivation for Choosing a Teaching Profession]. In MMK: sborník př́spevkư z mezinárodní védecké konference (pp. 1213-1221). Hradec Králove: Magnanimitas.

Tomšik, R. (2016a). Longitudinal validation of scale of motivation for choosing teaching as a career SMVUP3-S: Test-retest reliability and internal integrity. The Slavonic Pedagogical Studies Journal, 5(2), 311-319.

Tomšik, R. (2016b). Relationship between motivation of choosing teaching as a career and study choice satisfaction among Slovak teacher trainees. Slavonic Pedagogical Studies Journal,5(1), 3-13.

Tomšik, R. (2016c). The scale of motivations for choosing teaching as a career SMVUP-2-S. In $P h D$ Existence 6: česko-slovenská psychologická konference (nejen) pro doktorandy a o doktorandech: výzkum vs. praxe. Konvikt - Umělecké centrum Univerzity Palackého (pp. 317-332). Olomouc: UP.

Tomšik, R. (2016d). Prečo sme sa stali učitel’mi [Why did we become teachers]. Báčsky Petrovec: SVC.

Tomšik, R., \& Čerešník, M. (2017). Differences in motivation of choosing teaching as a profession among teacher trainees of STEM and non-STEM study programs. TEM Journal-Technology Education Management Informatics, 6(2), 400-406.

Tomšik, R. (2018a). Conscientiousness as a predictor of intrinsic motivation for choosing teaching as a career and academic achievement. In, PhD existence 2018: psychologie v dobè internetu. Česko-slovenská psychologická konference (nejen) pro doktorandy a o doktorandech (pp. 28-35). Olomouc: UP.

Tomšik, R. (2018b). Štýly výchovy a osobnostné charakteristiky vo vztahu k motivácii vol'by učitel'ského povolania [Parenting styles and personality dimension in relation to the motivation for choosing a teaching profession]. Nitra: PF UKF.

Tomšik, R., \& Gatial, V. (2018). Choosing teaching as a profession: Influence of big five personality traits on fallback career. Problems of Education in the 21st Century, 76(1), 100-108. 
Watt, H. M. G., \& Richardson, P. W. (2007). Motivational factors influencing teaching as a career choice: Development and validation of the FIT-Choice scale. The Journal of Experimental Education, 75, 167-202.

Watt, H. M. G., \& Richardson, P. W. (2008). Motivational Factors influencing teaching as a career choice: Development and validation of the FIT-Choice Scale. The Journal of Experimental Education, 75(3), 167-202

Watt, H. M. G., \& Richardson. P. W. (2012). An introduction to teaching motivations in different countries: Comparisons using the FIT-Choice scale. Asia-Pacific Journal of Teacher Education, 40, 185-197.

Watt, H. M. G., Richardson, P. W., \& Devos, C. (2013). (How) does gender matter in the choice of a STEM teaching career and later teaching behaviours? International Journal of Gender, Science and Technology, 5(3), 187-206.

Watt, H. M. G., Richardson, P. W., \& Pietsch. (2013). Choosing to teach in the "STEM" disciplines: Characteristics and motivations of science, ICT, and mathematics teachers. Mathematics: Essential Research, Essential Practice, 2, 795-804.

Received: April 06, 2019

Accepted: July 30, 2019

OF EDUCATION

IN THE $21^{\text {st }}$ CENTURY

Vol. 77, No. 4, 2019

559

$\begin{array}{ll}\text { Robert Tomšik } & \text { PaedDr., PhD., Researcher, Methodologist, Research Institute for Child } \\ & \text { Psychology and Pathopsychology (VÚDPaP), Cyprichova 42, } 831 \text { 05, Bratislava, } \\ & \text { Slovakia. } \\ & \text { E-mail: robert.tomsik@vudpap.sk } \\ & \text { Website: https://vudpap.sk/ }\end{array}$

